\title{
Reactors, enriched uranium and NPT
}

The United States should think again about its decision not to supply enriched uranium for a German research reactor, which gives a poor impression in advance of next year's non-proliferation conference.

THE multi-faceted row that has blown up in Germany over the nuclear fuel for a new research reactor at Garching, near Munich, will have echoes well outside Bavaria (see page 89). Indeed, it raises a principle that will inform, and possibly inflame, the conference next year at which the Non-Proliferation Treaty (NPT) will be reviewed, possibly for the last time if its current members cannot agree on the terms on which it should be continued. For what is happening will raise in the minds of many non-nuclear governments the question of whether the nuclear powers that sponsored the NPT are serious about their undertaking to provide technical assistance for peaceful projects undertaken by signatories of the treaty. It is, of course, ironical that the victim in this case should be technically advanced and law-abiding Germany.

There is, of course, nothing in the NPT to prevent the use of highly enriched uranium fuel in civil reactors (that at Garching is meant to generate neutrons for research), even though the same material could be used for making bombs. The assumption (and the solemn obligation of the signatories) is that the material will be subjected to whatever safeguards are needed to ensure that it is not diverted to military uses.

The unwillingness of the United States to supply Germany with the fuel it wants stems from domestic legislation - the Nuclear Non-Proliferation Act (NNPA) going back to President Jimmy Carter's time. That was when US electricity utilities, faced with new high costs for reprocessing uranium fuel, decided that it might be more economical to store it unprocessed against the revival of the market in fissile material that has not yet materialized. So why not make a virtue out of economic prudence by requiring that nuclear trading partners of the United States should similarly avoid reprocessing? And why not go one administrative step further, and decline to supply fissile material that could be used for making bombs?

To be fair, in declining to supply Germany with enriched fuel, the US government is faithfully echoing the spirit of the report of the National Academy of Sciences committee that earlier this year came close to recommending that the United States should use its whole influence to prevent the physical production of plutonium and enriched uranium elsewhere in the world. The common interest in non-proliferation notwithstanding, there are good grounds for believing that it would instead be preferable to face up to the difficulties of providing international custodianship for fissile material (see Nature 367, 301-302 \& 307; 1994), which will be needed anyway. But the issue that faces Germany now, and which is certain to arise at the review conference next year, is whether it is equitable that paid-up members of the NPT should be subjected to requirements in the conduct of their peaceful nuclear business that go beyond the treaty proper.

In reality, there are two serious objections. First, it appears to have been forgotten in the United States that the NPT is meant to be a bargain between nuclear and non-nuclear powers. In return for self-denial on nuclear weapons, nonnuclear states would be given (again under international safeguards) technical assistance in peaceful nuclear energy. In practice, there has been very little business since the NPT was negotiated in the late $1960 \mathrm{~s}$, but that does not change the principle. The non-nuclear members of the NPT will rightly ask what has happened to the other side of the bargain they signed at the review conference next year. But there is another danger. If even countries such as Germany are unable to rely on international trade in nuclear energy, will that not confirm them in the belief that self-sufficiency is essential? And will that not eventually imply a proliferation of enrichment and reprocessing plants?

For the nuclear powers and all those with an interest in avoiding the spread of nuclear weapons, next year's NPT conference will be a crucial proceeding. The most serious danger, of course, is that those who have found the treaty so far to have been an irksome burden (and an extra cost) will defect. Germany is unlikely to be one of them, whatever happens about the fuel for Garching. But the principle of the ordinary marketplace, that those who have struck a bargain have a right to expect that their entitlements as well as their obligations will materialize, applies (or should apply) to international treaties as well. The entitlements cannot be wished away by administrative action elsewhere.

\section{Education gains}

American children are called "prisoners of time" in a report comparing US schools to Germany and Japan.

ONCE again, education is edging close to the forefront of political attention in the United States and elsewhere as various groups point to obvious flaws in the way children are now taught basic subjects, science and mathematics included. On education in its broadest sense, the National Education Commission on Time and Learning (created by 